\title{
Scintillation 2D-matrices for digital tomography
}

\author{
E.F.Voronkin, V.D.Ryzhikov, B.V.Grinyov, E.Y.Shevchenko \\ Institute for Scintillation Materials, STC "Institute for Single Crystals", \\ National Academy of Sciences of Ukraine, \\ 60 Lenin Ave., 61001 Kharkiv, Ukraine
}

Received April 2, 2015

\begin{abstract}
A possibility is shown of tomography applications of scintillation $2 \mathrm{D}$ matrices based on aluminum-doped zinc selenide $(\mathrm{ZnSe}(\mathrm{Al}))$. Procedures for preparation of multi-element matrices are described, as well as results on inter-element interference. For the first time, chalcogenide scintillators based on zinc selenide were tested on biological objects (blood vessels) at "Filips", Israel, for detection of cholesterol plaques.
\end{abstract}

Keywords: scintillation 2D matrices, digital tomograph.

Показана возможность применения сцинтилляционных 2D матриц на основе селенида цинка, легированного алюминием (ZnSe(Al)) для томографов. Приведены методики изготовления многоэлементных матриц и результаты контроля взаимовлияния между элементами. Впервые показаны результаты испытания халькогенидных сцинтилляторов селенида цинка на биологических объектах (кровяных сосудах) по выявлению холистириновых бляшек на фирме "Filips" Израиль.

Сцинтиляційні 2D-матриці для цифрової томографії. Є.Ф.Воронкін, В.Д.Рижиков, Ю.В.Малюкін, Б.В.Гріньов, Є.І. Шевченко.

Показано можливість використання сцинтиляційних латриць на основі селеніду цинку, легованого алюлінієм (ZnSe(Al)) для томографії. Приведено методики виготовлення багатоелементних матриць та результати контролю взаємовпливу між элементами. Вперше показано результати випробування халькогенідних сцинтиляторів селеніду цинку на біологічних зразках (кров'яних судинах) за визначення холестиринових бляшок на фірмі "Filips" (Ізраїль).

\section{Introduction}

Digital images, as compared with those on analog film carriers, can be much more easily studied, processed and stored. Digital tomographs operate on the real time scale, and the images can be obtained instantly. Multiple images can be archived, which allows analyzing the progress of disease or sanation at any desired moment. Digital images can be sent via e-mail without loss of quality (256 shades of grey color) to consult specialists of leading medical centers [1].

The present development is based on scintillation technologies and can be used in production of multi-element assemblies (2Dmatrices) for visualization of radiation in systems of radiation monitoring, non-destructive testing and medical tomography.

The main principle for determination of resolution of a scintillation matrix is considering the radiation detection process as a sum total of the constituent processes. The process of gamma-radiation detection in the scintillation matrix can be described as: 1) absorption of gamma-quanta and generation of light in the crystal; 2) collection of light and its path to the photodiode; 3) shapsing of the electric pulse by the photodiode; 4) amplification and detection of 

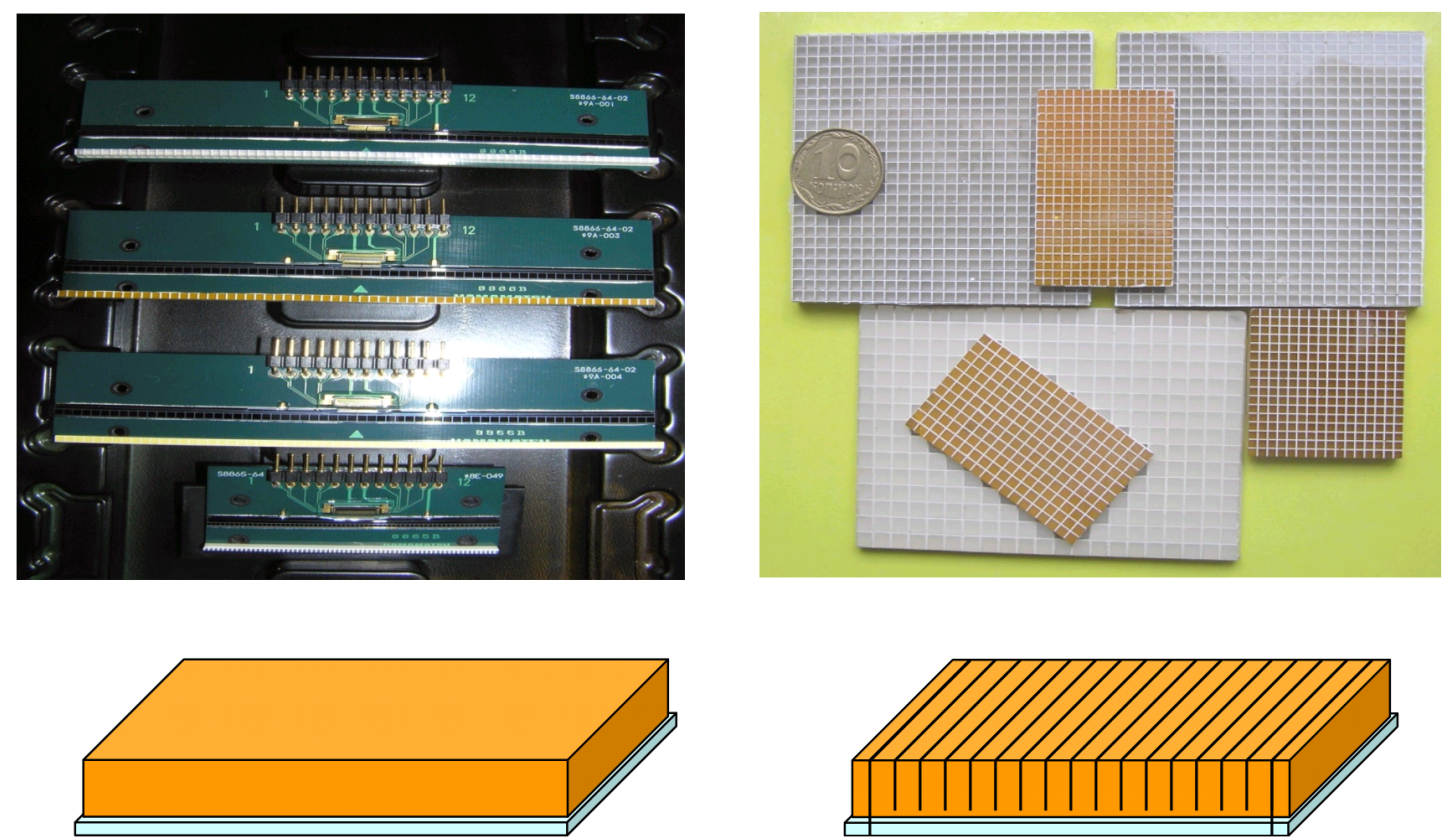

a)

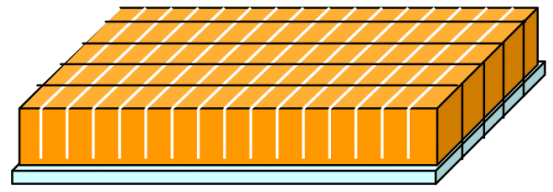

b)

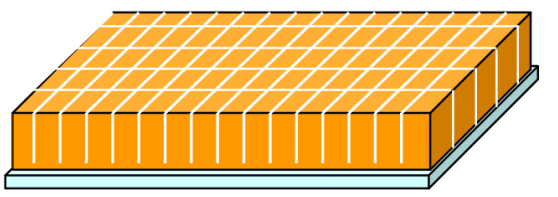

c)

Fig. 1. Scintillation workpiece glued to the substrate. Fig. 1a, b, c - scintillation workpiece cut into 16 channels.

the electric signal coming from the photodiode.

The intrinsic resolution of a scintillator crystal is related to many effects, such as non-uniformity of its scintillation efficiency, non-uniformity of reflecting ability of the reflector, as well as non-proportionality of the scintillator response with respect to the energy of gamma-quanta.

Gamma-quanta, when absorbed by the scintillator, generate electrons and holes as a result of photoeffect. In the scintillator, these electrons pass their energy to a light pulse or heat (in the case of non-radiative recombination). To lower the light losses, the scintillation material should be of high optical quality, and its side surfaces should have high reflective ability to decrease the probability of signal flow to neighboring pixels.

Application of metal (silver) reflective coating (as compared with traditional powder reflectors) minimizes inter-channel interference in the scintillation matrix due to suppression of movement of the photoelectrons formed from one pixel to another.

\section{Results}

Our task was to develop a more simple and cost-saving method for preparation of multi-element assemblies, which should have high spatial resolution in the low-energy range of $\mathrm{X}$-ray radiation.

This is achieved by cutting a plate of the scintillation material of the required size into required number of elements in two mutually perpendicular directions; between them, metal (silver) reflectors are placed. As a scintillation material, we use aluminum-doped zinc selenide $(\mathrm{ZnSe}(\mathrm{Al}))[2]$. Before cutting, a plate of this material is fixed on a light reflecting substrate.

This method of preparation is simple and not expensive, because there is no need to fabricate individual elements separately they are obtained from one plate that is inflexibly fixed on a substrate. The plate is cut into elements in two mutually perpendicular directions. No additional accessories 


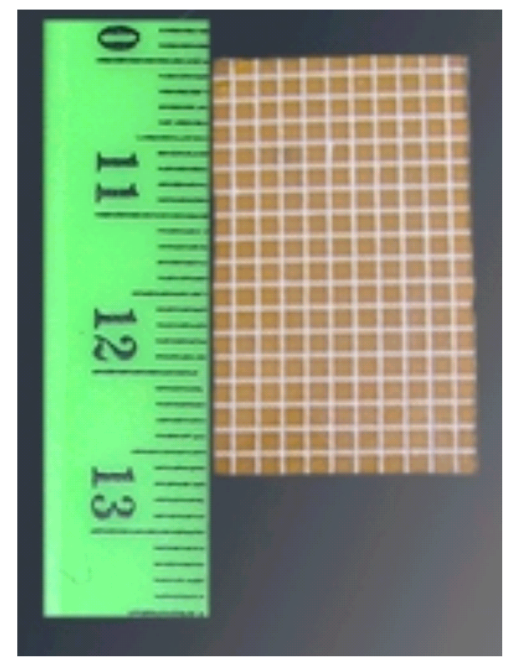

Fig. 2. Photograph of 198-pixel scintillation matrix of $\mathrm{ZnSe}(\mathrm{Al})$.

are needed. After cutting, no polishing of the sides of each element is needed, which minimizes fissuring and cracking. Equal geometrical dimensions of all the elements are ensured, as well as equal thickness of reflector between the elements. This procedure allows preparation of multi-element arrays and matrices with $1 \times 1 \mathrm{~mm}^{2}$ minimum size of each element. Scintillation matrices obtained by this method ensure sharp images, i.e., high spatial resolution of the assembly (array, matrix) [3].

The $\mathrm{ZnSe}(\mathrm{Al})$ scintillator used in our work shows good optical matching with the photodiode. It is characterized by high sensitivity, wide dynamic range $\left(10^{4}\right)$ and fast response in the low-energy range (30$50 \mathrm{keV}$ ) of $\mathrm{X}$-ray radiation.

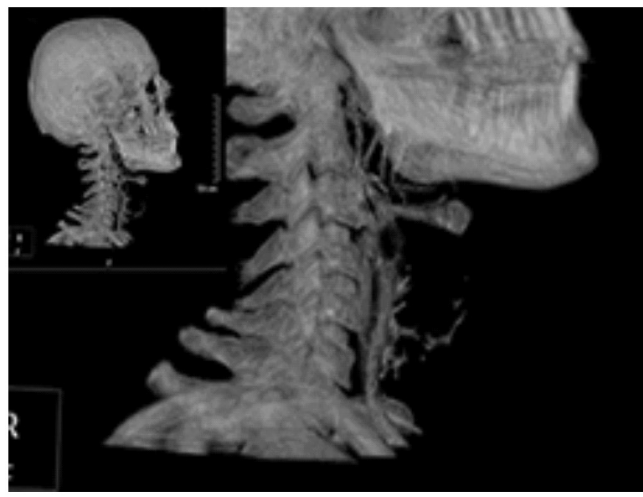

a)
The use of a reflective substrate and metal light reflector between pixels ensures high light output and prevents interference between channels, which also favors high sensitivity and spatial resolution.

Suitable materials for the substrate are light-reflecting ceramics or fluoroplastics. Metal coatings of silver, indium or aluminum can be used as reflectors.

Fig. 1 presents step-by-step drawings of the matrix preparation technology.

Fig. 2 shows a photo of the 198-pixel scintillation matrix of $\mathrm{ZnSe}(\mathrm{Al})$.

Fig. 3 shows tomographic images (of a human patient) obtained using $\mathrm{CdWO}_{4}$ crystals (a) and $\mathrm{ZnSe}(\mathrm{Al})$ matrices (b).

As it can be seen, in the latter case the blood artery with a neoplasm (cholesterol plaque) can be discerned much more clearly. The image obtained without the low-energy component shows the blood vessel only vaguely, and the neoplasm cannot be noticed at all.

Fig. 4 shows three-dimensional hystograms of inter-channel interference in $\mathrm{ZnSe}(\mathrm{Al})$ scintillation matrices with different light-reflecting coatings.

When a metal layer is deposited onto the side surfaces of each pixel of the scintillation matrix, the interference is reduced by two times, improving the image sharpness. Also, the use of metal reflector increases the relative light output of the matrix, which positively affects the quality of the tomographic examination.

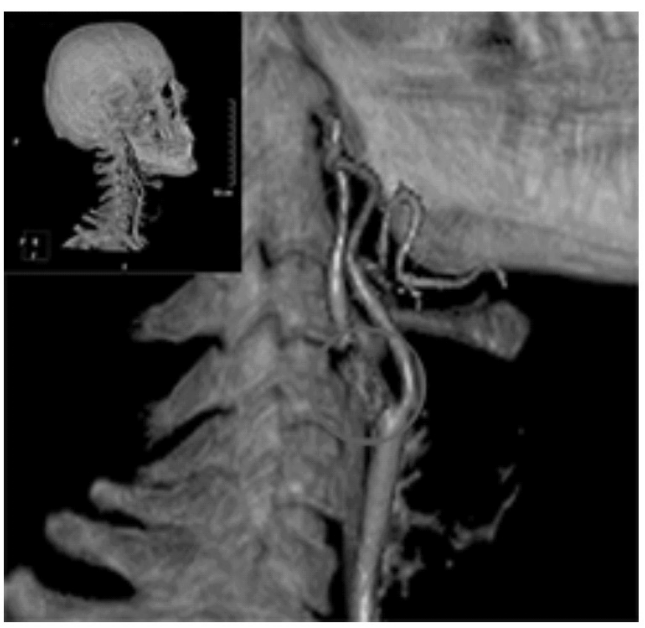

b)

Fig. 3. Tomographic images obtained with single crystal $\mathrm{CdWO}_{4}$ (a) and using $2 \mathrm{D}$-matrix based on $\mathrm{ZnSe}(\mathrm{Al})(\mathrm{b})$. 

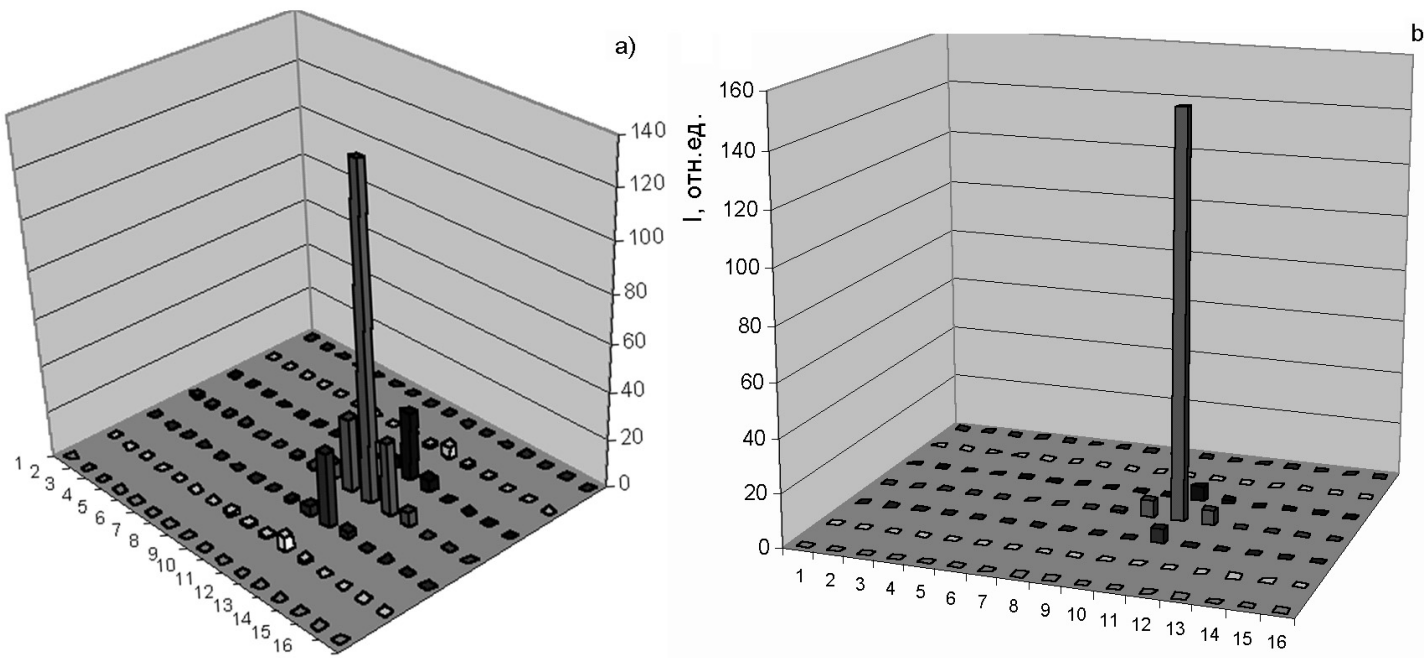

Fig. 4. Three-dimensional histogram showing pixel interference in $\mathrm{ZnSe}(\mathrm{Al})$ scintillation matrix with powder light reflector (a) and metal reflector (b).

\section{Experimental}

It is required to fabricate a $\mathrm{ZnSe}(\mathrm{Al}) \mathrm{ma}$ trix containing 3136 pixels, The pixel size is $1 \times 1 \times 0.6 \mathrm{~mm}$, the light-reflecting channel width is $0.3 \mathrm{~mm}$. The ready $\mathrm{ZnSe}(\mathrm{Al})$ plate workpiece of an arbitrary size and thickness $0.6 \mathrm{~mm}$ is glued onto ceramic light-reflecting substrate. The workpiece is fixed on a machine tool with diamond saw with outside cutting rim. The first basic cutting is made in such a way that the saw cuts the workpiece and the light-reflecting substrate through. Then 55 cuts are made with step $1.3 \mathrm{~mm}$. The workpiece plate is cut to $0.6 \mathrm{~mm}$ depth to reach the light-reflecting ceramic substrate. The last cut, like the basic one, is made with $1.3 \mathrm{~mm}$ step. The workpiece that was cut in this way is rotated by $90^{\circ}$ and further cut into 56 channels in a similar manner. The workpiece that was cut in two mutually perpendicular directions is taken out from the machine tool and rinsed in an ultrasonic bath to remove cutting chips from the side surfaces. Then light-reflecting metal (silver) layer is applied onto side surfaces of the channels. The matrix channels are filled with adhe- sive to ensure rigidity. After polymerization of the adhesive, the scintillation matrix is ready.

\section{Conclusions}

The proposed technology allows preparation of 2D-matrices with high spatial resolution of shadow X-ray images. This method can be realized without specially designed complex accessories, it is simple, not expensive, and readily reproducible for full-scale production.

The produced 198-pixel scintillation matrices on the basis of aluminum-doped zinc selenide $(\mathrm{ZnSe}(\mathrm{Al}))$ crystals have been tested on a two-energy tomograph in Israel. It was possible to detect formation of cholesterol plaques inside human blood vessels.

Procedure for testing of multi-element scintillation matrices for check-up of channel interference has been developed, and advantages of using metal light reflectors have been shown.

\section{References}

1. E.Voronkin, Functional Materials, 21, 1 (2014).

2. Patent of Ukraine, 92286 (2009). 